\title{
Drip Fertigation and Black Plastic Mulching for Improved Productivity in Chilli
}

\author{
V. Navaneetha Pandian*, M. Selvamurugan and I. Muthuchamy \\ Precision Farming Development Centre, Department of Soil and Water Conservation \\ Engineering, Agricultural Engineering College and Research Institute, Tamil Nadu Agricultural \\ University, Coimbatore - 641 003, Tamil Nadu, India \\ *Corresponding author
}

\section{A B S T R A C T}

A field experiment was conducted to assess the effect of drip fertigation and plastic mulching on Chilli hybrid Sneha - 7044 at Precision Farming Development Centre farm, Tamil Nadu Agricultural University, Coimbatore. The experiment was laid out in a randomized block design with 9 treatments and 3 replications. The treatments are

\section{Keywords}

Plastic mulch, Drip irrigation, Fertigation, Chilli.

\section{Article Info}

Accepted:

20 September 2017

Available Online:

10 November 2017 consisting of 3 mulching levels of Black plastic mulch of 50 micron thickness, 25 micron thickness and No mulch, and 3 fertilizer levels of $80 \%, 100 \%$ and $120 \%$ of Recommended Dose of Fertilizers (RDF). The results of the study showed that the different levels of drip irrigation and plastic mulching significantly influenced the plant growth parameters of chilli. Among the various treatments, Black Plastic mulch of 25 micron thickness and drip fertigation with 120\% RDF (144: 96: $96 \mathrm{~kg}$ of NPK/ ha) recorded maximum plant height and number of primary branches of $86.27 \mathrm{~cm}$ and 8.00 respectively. The maximum yield attributes viz., green chilli length, 100 green chilli weight, number of fruits per plant and dry matter production of $12.21 \mathrm{~cm}, 418 \mathrm{~g}, 287$ and $156 \mathrm{~kg} / \mathrm{ha}$, respectively were observed in Black Plastic mulch of 25 micron thickness and fertigation with $120 \%$ RDF $\left(\mathrm{T}_{3}\right)$. The highest green chilli yield of $9410 \mathrm{~kg} / \mathrm{ha}$ was recorded in the black plastic mulch of 25 micron thickness along with fertigation@ $120 \%$ RDF compared to other treatments. The response of Chilli on black plastic mulch with drip fertigation were found to have higher moisture conservation, high yield, maximum water use efficiency, maximum fertilizer use efficiency and higher weed control.

\section{Introduction}

In India, the irrigated area consists of about 36 per cent of the net sown area. Presently the agricultural sector accounts for about 83 per cent of all water uses. Increasing competition with the other sectors in the future would limit the water availability for expanding irrigated area. The demand of water for agricultural purpose is estimated to increase from $50 \mathrm{M}$ ha $\mathrm{m}$ in 1985 to $70 \mathrm{M}$ ha $\mathrm{m}$ by
2050 (Sivanappan, 2005). The World Water Council believes that by the year 2020 we shall need 17 per cent more water than presently available to feed the world (Suryawanshi, 1995). Hence, for successful agriculture, proper utilization of water is very essential which means to increase the water use efficiency of a crop by adopting different water conservation measures. The traditional 
surface irrigation methods are not reliable and we are fore fronted with many problems regarding soil and water. The water loss takes place in nature due to evaporation, transpiration and percolation. The percolation losses can be avoided by applying water to the root zone of plants through drip irrigation systems. The evaporation losses can be minimized by the use of mulches such as crop wastes and polyethylene plastics. Mulching is the process or practice of covering the soil to make more favourable conditions for plant growth, development and efficient crop production. Mulch technical term means 'covering of soil'. Now a days, Black plastic is the predominate mulch utilized for vegetable production. It requires higher cost per acre compared to other mulches. However, black plastic mulch also effectively warms the soil, improving early crop production and eliminates most in-row weed growth. The use of black plastic mulches typically results in higher yields and quality in vegetable crops enhancing profitability for the grower.

Fertigation is a new concept recently practiced in several parts of the world in horticultural crops. It offers a right mixture of water and nutrients to the crop through drip system, and thus meeting plants water and nutrient requirements in most efficient possible manner (Patel et al., 2001).

It also provides essential elements directly to active root zone thus minimize losses of expensive fertilizer which ensures higher and quality yield along with saving in time and labour (Patel and Rajput, 2001). Experiments have already indicated that through fertigation 40 to 50 per cent of nutrients could be saved.

Chilli (Capsicum annuum L.) is an important spice crop and belonging to the family Solanaceae. Chilli is widely cultivated throughout warm temperature, tropical and sub-tropical regions of India. To increase the productivity, developing comprehensive package of practices of Chilli using plasticulture techniques is necessary. With this in view, the study was made to study the effect of different levels of drip fertigation and plastic mulching on growth and yield of Chilli.

\section{Materials and Methods}

A field experiment was conducted to evaluate the effect of drip fertigation and plastic mulching on plant growth and yield of Chilli at Farms of Precision Farming Development Centre, Department of Soil and Water Conservation Engineering, Tamil Nadu Agricultural University, Coimbatore. The soil of the experimental field was categorized as clay loam. The soil was neutral in reaction with low in organic carbon, available nitrogen and phosphorus and medium in available potassium. Normal weather conditions prevailed during the crop growth period. The experiment was laid out in a factorial randomized block design with 9 treatments and 3 replications. The treatments are consisting of 3 mulching levels of Black plastic mulch of 50 micron thickness, 25 micron thickness and No mulch, and 3 fertilizer levels of $80 \%, 100 \%$ and $120 \%$ of Recommended Dose of Fertilizers (RDF).

\section{Treatment details}

$\mathrm{T}_{1}$ : Black Plastic mulch of 25 micron thickness and fertigation with $80 \%$ RDF

$\mathrm{T}_{2}$ : Black Plastic mulch of 25 micron thickness and fertigation with 100\% RDF

$\mathrm{T}_{3}$ : Black Plastic mulch of 25 micron thickness and fertigation with $120 \%$ RDF

$\mathrm{T}_{4}$ : Black Plastic mulch of 50 micron thickness and fertigation with $80 \%$ RDF 
$\mathrm{T}_{5}$ : Black Plastic mulch of 50 micron thickness and fertigation with $100 \%$ RDF

$\mathrm{T}_{6}$ : Black Plastic mulch of 50 micron thickness and fertigation with $120 \%$ RDF

$\mathrm{T}_{7}$ : No mulch with $80 \%$ RDF drip fertigation

$\mathrm{T}_{8}$ : No mulch with $100 \%$ RDF drip fertigation

$\mathrm{T}_{9}$ : No mulch with $120 \%$ RDF drip fertigation

(RDF: 120: 80: $80 \mathrm{~kg} / \mathrm{ha})$

The experimental plot was thoroughly ploughed with disc plough and repeatedly tilled with cultivator to bring optimum soil tilth and leveled land area was divided into 27 plots of $12.15 \mathrm{~m}^{2}$. The treatments were allocated to each plot by following random principle. Thereafter raised beds were formed with $120 \mathrm{~cm}$ width and $20 \mathrm{~cm}$ height. The laterals were laid in each bed. On line drippers of 4 lit $h^{-1}$ were used at a spacing of $60 \mathrm{~cm}$.

Over the drip line according to the treatment mulching sheets were spread in each plot and holes were punched where seedlings were to be established. Both ends of the plastic sheet were buried into the soil upto a depth of $10 \mathrm{~cm}$. Healthy seedlings of Chilli hybrid Sneha-7044 was planted in raised beds with a spacing of $60 \mathrm{~cm}$ between rows and $45 \mathrm{~cm}$ within row as a paired row geometry.

Other management practices like gap filling, weeding and plant protection measures were carried out according to the recommended package of practices. The various growth, yield and quality parameters were recorded at appropriate stages by selecting ten plants randomly in the net plot area of individual treatments and green chilli yield was observed from the net plot area and its mean yield was multiplied to one hectare area.

\section{Results and Discussion}

In this study, results showed that the different levels of drip irrigation and plastic mulching significantly influenced the plant growth parameters of chilli. Among the various treatments, Black Plastic mulch of 25 micron thickness and drip fertigation with $120 \%$ RDF (144: 96: $96 \mathrm{~kg}$ of NPK/ ha) recorded maximum plant height and number of primary branches of $86.27 \mathrm{~cm}$ and 8.00 respectively (Table 1 and 2). The minimum plant height of $66.60 \mathrm{~cm}$ and lowest number of primary branches of 6.33 was recorded in no mulch plot with $80 \%$ RDF (Table 1 and 2). Similar results were reported by Hallidri (2001) that plant height was maximum in plants grown on black and transparent polythene mulch than control (bare soil). The increase in plant height is attributed to moisture conservation and weed suppression due to application of mulches (Ullah et al., 1998). The maximum yield attributes viz., green chilli length, 100 green chilli weight, number of fruits per plant and dry matter production of $12.21 \mathrm{~cm}, 418 \mathrm{~g}$, 287 and $156 \mathrm{~kg} / \mathrm{ha}$, respectively were observed in Black Plastic mulch of 25 micron thickness and fertigation with $120 \% \mathrm{RDF}\left(\mathrm{T}_{3}\right)$ (Table 3).

The lowest green chilli length, 100 green chilli weight, number of fruits per plant and dry matter production of $10.58 \mathrm{~cm}, 359 \mathrm{~g}, 239$ and $121 \mathrm{~kg} / \mathrm{ha}$, respectively were registered in No mulch and fertigation with $80 \%$ RDF (Table 3). The above results are in good agreement with the finding of Tumbare and Bhoite (2002). Black Plastic mulching stimulated the plant growth results enhanced yield attributes and higher fruit yield in chilli. Black Plastic Mulching produced maximum yield attributes compared to no mulching. This increase in the yield attributes was probably associated with the conservation of moisture and improved microclimate both beneath and above the soil surface. 
Table.1 Effect of drip fertigation and mulching on plant height of chilli

\begin{tabular}{|l|c|c|c|}
\hline \multirow{2}{*}{ Treatments } & \multicolumn{3}{|c|}{ Plant height (cm) } \\
\cline { 2 - 4 } & 30 DAT & 60 DAT & 90 DAT \\
\hline $\mathrm{T}_{1}$ : Plastic mulch @ 25 micron \& 80\% RDF & 51.95 & 69.09 & 76.11 \\
\hline $\mathrm{T}_{2}:$ Plastic mulch @ 25 micron \& 100\% RDF & 56.25 & 73.29 & 80.39 \\
\hline $\mathrm{T}_{3}:$ Plastic mulch @ 25 micron \& 120\% RDF & 59.27 & 78.22 & 86.27 \\
\hline $\mathrm{T}_{4}$ : Plastic mulch @ 50 micron \& 80\% RDF & 50.24 & 68.86 & 75.08 \\
\hline $\mathrm{T}_{5}$ : Plastic mulch @ 50 micron \& 100\% RDF & 54.11 & 72.17 & 78.14 \\
\hline $\mathrm{T}_{6}$ : Plastic mulch @ 50 micron \& 120\% RDF & 57.07 & 75.68 & 82.69 \\
\hline $\mathrm{T}_{7}:$ No mulch with 80\% RDF & 44.97 & 61.40 & 66.60 \\
\hline $\mathrm{T}_{8}:$ No mulch with 100\% RDF & 50.11 & 66.76 & 73.65 \\
\hline $\mathrm{T}_{9}:$ No mulch with 120\% RDF & 53.26 & 70.10 & 78.13 \\
\hline SEd & 3.87 & 4.94 & 5.28 \\
\hline CD (0.05) & 8.20 & 10.47 & 11.19 \\
\hline
\end{tabular}

Table.2 Effect of drip fertigation and mulching on number of primary branches/ plant of chilli

\begin{tabular}{|l|c|c|c|}
\hline \multirow{2}{*}{ Treatments } & \multicolumn{3}{|c|}{ No. of Primary branches/ plant } \\
\cline { 2 - 4 } & $30 \mathrm{DAT}$ & $60 \mathrm{DAT}$ & 90 DAT \\
\hline $\mathrm{T}_{1}$ : Plastic mulch @ 25 micron \& 80\% RDF & 4.53 & 5.78 & 6.73 \\
\hline $\mathrm{T}_{2}$ : Plastic mulch @ 25 micron \& 100\% RDF & 4.68 & 5.95 & 7.07 \\
\hline $\mathrm{T}_{3}$ : Plastic mulch @ 25 micron \& 120\% RDF & 4.90 & 6.25 & 8.00 \\
\hline $\mathrm{T}_{4}$ : Plastic mulch @ 50 micron \& 80\% RDF & 4.48 & 5.73 & 6.65 \\
\hline $\mathrm{T}_{5}$ : Plastic mulch @ 50 micron \& 100\% RDF & 4.60 & 5.80 & 6.91 \\
\hline $\mathrm{T}_{6}$ : Plastic mulch @ 50 micron \& 120\% RDF & 4.83 & 6.08 & 7.48 \\
\hline $\mathrm{T}_{7}$ : No mulch with 80\% RDF & 4.26 & 5.58 & 6.33 \\
\hline $\mathrm{T}_{8}$ : No mulch with 100\% RDF & 4.46 & 5.70 & 6.51 \\
\hline $\mathrm{T}_{9}$ : No mulch with 120\% RDF & 4.61 & 5.80 & 6.82 \\
\hline SEd & 0.11 & 0.13 & 0.68 \\
\hline CD (0.05) & 0.23 & 0.28 & 1.45 \\
\hline
\end{tabular}

Table.3 Effect of drip fertigation and mulching on fruit length, 100 green chilli weight, number of fruits per plant and dry matter production in chilli

\begin{tabular}{|c|c|c|c|c|}
\hline Treatments & $\begin{array}{c}\text { Green chilli } \\
\text { length }(\mathrm{cm})\end{array}$ & $\begin{array}{c}100 \text { green chilli } \\
\text { weight }(\mathrm{g})\end{array}$ & $\begin{array}{c}\text { Number of } \\
\text { fruits/plant }\end{array}$ & DMP $(\mathrm{kg} / \mathrm{ha})$ \\
\hline $\mathrm{T}_{1}:$ Plastic mulch @ 25 micron \& 80\% RDF & 10.97 & 396 & 258 & 129 \\
\hline $\mathrm{T}_{2}:$ Plastic mulch @ 25 micron \& 100\% RDF & 11.83 & 407 & 272 & 136 \\
\hline $\mathrm{T}_{3}$ : Plastic mulch @ 25 micron \& 120\% RDF & 12.21 & 418 & 287 & 156 \\
\hline $\mathrm{T}_{4}:$ Plastic mulch @ 50 micron \& 80\% RDF & 10.92 & 390 & 250 & 128 \\
\hline $\mathrm{T}_{5}:$ Plastic mulch @ 50 micron \& 100\% RDF & 11.74 & 405 & 264 & 134 \\
\hline $\mathrm{T}_{6}$ : Plastic mulch @ 50 micron \& 120\% RDF & 11.87 & 412 & 279 & 149 \\
\hline $\mathrm{T}_{7}:$ No mulch with 80\% RDF & 10.58 & 359 & 239 & 121 \\
\hline $\mathrm{T}_{8}:$ No mulch with 100\% RDF & 10.90 & 381 & 247 & 125 \\
\hline $\mathrm{T}_{9}$ : No mulch with 120\% RDF & 11.12 & 400 & 252 & 129 \\
\hline SEd & 0.63 & 5.23 & 7.16 & 8.42 \\
\hline $\mathrm{CD}(0.05)$ & 1.34 & 11.09 & 15.18 & 17.85 \\
\hline
\end{tabular}


Table.4 Effect of drip fertigation and mulching on green chilli yield

\begin{tabular}{|c|c|}
\hline Treatments & Green Chilli Yield (kg/ha) \\
\hline $\mathrm{T}_{1}$ : Plastic mulch @ 25 micron \& 80\% RDF & 7815 \\
\hline $\mathrm{T}_{2}$ : Plastic mulch @ 25 micron \& 100\% RDF & 8350 \\
\hline $\mathrm{T}_{3}$ : Plastic mulch @ 25 micron \& 120\% RDF & 9410 \\
\hline $\mathrm{T}_{4}$ : Plastic mulch @ 50 micron \& 80\% RDF & 7500 \\
\hline $\mathrm{T}_{5}$ : Plastic mulch @ 50 micron \& 100\% RDF & 7902 \\
\hline $\mathrm{T}_{6}$ : Plastic mulch @ 50 micron \& 120\% RDF & 8800 \\
\hline $\mathrm{T}_{7}:$ No mulch with 80\% RDF & 6319 \\
\hline $\mathrm{T}_{8}:$ No mulch with 100\% RDF & 6913 \\
\hline $\mathrm{T}_{9}:$ No mulch with 120\% RDF & 7550 \\
\hline $\mathrm{SEd}$ & 287 \\
\hline $\mathrm{CD}(0.05)$ & 608 \\
\hline
\end{tabular}

The highest green chilli yield of $9410 \mathrm{~kg} / \mathrm{ha}$ was recorded in the black plastic mulch of 25 micron thickness along with fertigation @ $120 \%$ RDF compared to other treatments (Table 4). The lowest green chilli yield (6319 $\mathrm{kg} / \mathrm{ha}$ ) was recorded in the no mulch and fertigation with $80 \%$ RDF (Table 4). The increase in green chilli yield was $3091 \mathrm{~kg} / \mathrm{ha}$ in the black plastic mulch of 25 micron thickness along with fertigation @ 120\% RDF (144: 96: $96 \mathrm{~kg}$ of NPK/ ha) over the nomulch treatment with $80 \%$ RDF (T7) (Table 4). Similarly, Veeranna et al., (2001) recorded a yield increase of 9 per cent with the adoption of drip irrigation over furrow method. The increase in yield might be due to better proportion of air-soil-water and suppressed weed growth which was maintained throughout the life period of crop in plastic mulching and drip fertigation @ $120 \%$ RDF as reported by Ashrafuzzaman et al., (2011). The increased yield in fertigation treatments might be due to better availability of plant nutrients and irrigation water throughout the crop growth period under drip fertigation system. This is in accordance with the findings of Gutal et al., (1992). The response of Chilli on black plastic mulch with drip fertigation were found to have higher moisture conservation, high yield, maximum water use efficiency, maximum fertilizer use efficiency and higher weed control.
The result of the present study revealed that the plant growth parameters, yield attributes and green chilli yield were enhanced by the combined effect of drip fertigation at $120 \%$ RDF (144: 96: $96 \mathrm{~kg}$ of NPK/ ha) along with 25 micron thickness black plastic mulching. Hence, the present study recommends the $120 \%$ RDF drip fertigation with 25 micron black plastic mulching to maximize the productivity in Chilli crop with effective utilization of water and nutrients.

\section{Acknowledgement}

The authors wish to express their gratitude to the National Committee in Plasticulture Applications in Horticulture (NCPAH), Government of India, Ministry of Agriculture, New Delhi for providing financial support for this study.

\section{References}

Ashrafuzzaman, M. Abdul Halim, M. R. Ismail, S.M. Shahidullah and M. A. Hossain. 2011. Effect of Plastic Mulch on Growth and Yield of Chilli (Capsicum annuum L.). BRAZILIAN ARCHIVES OF BIOLOGY AND TECHNOLOGY. 54(2): 321-330.

Gutal, G.B., Jadhav, S.S. and Takte, R.L. 1992. Effective surface covered 
cultivation in fruit vegetable crop tomato. Proc. of the Internat. Agri. Engg. Coni Bangkok, Thailand from 7-10 Dec.853-856.

Hallidri, M. 2001. Comparison of different mulching materials on growth, yield and quality of cucumber (Cucumis sativus L.). Acta Horticulturae, 559: 49-53.

Patel, N. and Rajput, T.B.S. (2001). Effect of fertigation on growth and yield of onion. Micro Irrigation, CBIP Publication, 282: 451.

Sivanappan, R.K. and M.V. Ranghaswami. 2005. Technology to take 100 tons per acre in Sugarcane. Kisan World, 32(10): 35-38.

Suryawanshi, S.K. 1995. Success of Drip in India: An Example to the Third World. In: Proceedings of $5^{\text {th }}$ International microirrigation Congress, April 2-6, Orlando, Florida. pp. 347-352.

Tumbare, A.D. and Bhoite, S.U. 2002, Effect of solid soluble fertilizers applied through fertigation on the growth and yield of chilli (Capsicum aпnиum L.). Indian Journal of Agricultural Sciences, 72(2): 109-111.

Ulah, R., Rashid, A., Khan, A. and Ghulam. S.1998. Effect of different mulching materials on the growth and production of wheat crop. Sarhad J. Agric., 14(1): 21-25.

Veerana, H. K. 2001, Effect of fertigation, irrigation and potassium levels on the productivity of chilli (Capsicum annuит L.). Ph.D. Thesis, University of Agricultural Sciences, Bangalore.

\section{How to cite this article:}

Navaneetha Pandian, V., M. Selvamurugan and Muthuchamy, I. 2017. Drip Fertigation and Black Plastic Mulching for Improved Productivity in Chilli. Int.J.Curr.Microbiol.App.Sci. 6(11): 2732-2737. doi: https://doi.org/10.20546/ijcmas.2017.611.322 